\title{
Communication \\ First Report on the Mechanisms of Insecticide Resistance in Field Populations of the Small Hive Beetle in Florida
}

\author{
Lambert H. B. Kanga ${ }^{1, * \mathbb{D}}$, Walker Marechal ${ }^{1}$ and Anthony Ananga ${ }^{2}$ \\ 1 Center for Biological Control, College of Agriculture and Food Sciences, Florida A\&M University, \\ Tallahassee, FL 32307, USA; marechalwr7@gmail.com \\ 2 Center for Viticulture and Small Fruits Research, College of Agriculture and Food Sciences, \\ Florida A\&M University, Tallahassee, FL 32308, USA; anthony.ananga@famu.edu \\ * Correspondence: lambert.kanga@famu.edu
}

check for updates

Citation: Kanga, L.H.B.; Marechal, W.; Ananga, A. First Report on the Mechanisms of Insecticide Resistance in Field Populations of the Small Hive Beetle in Florida. Agriculture 2021, 11, 559. https://doi.org/10.3390/ agriculture11060559

Academic Editor: Anna Andolfi

Received: 13 May 2021

Accepted: 16 June 2021

Published: 18 June 2021

Publisher's Note: MDPI stays neutral with regard to jurisdictional claims in published maps and institutional affiliations.

Copyright: (c) 2021 by the authors. Licensee MDPI, Basel, Switzerland. This article is an open access article distributed under the terms and conditions of the Creative Commons Attribution (CC BY) license (https:// creativecommons.org/licenses/by/ $4.0 /)$.

\begin{abstract}
The small hive beetle (Aethina tumida Murray) is a serious threat to beekeeping and crops that rely on honeybees for pollination. The small hive beetle not only causes significant damage to honeybees by feeding on pollen and honey, attacking bee brood and causing stored honey to ferment, but also might serve as a vector of diseases. In addition, the small hive beetle has developed resistance to the pyrethroid and organophosphate insecticides registered for control of honeybee pests in the United States. The development of resistance in small hive beetle populations is a great concern to the beekeeping industry; thus, there is an urgent need for strategies to manage that resistance. Therefore, we used synergist probes to determine the mechanisms of resistance in a small hive beetle population to these insecticides. Our studies on the toxicity of insecticides alone or with the synergists piperonyl butoxide (PBO) and S,S,S,-tributyl phosphorotrithionate (DEF) suggested that mixed-function oxidases and esterases were the major resistance factors to these insecticides in a studied population of the small hive beetle. In contrast, there was no synergism with diethyl maleate (DEM), triphenyl phosphate (TPP) and formamidine. Therefore, glutathione-S-transferase, carboxylesterase and target site were not involved in insecticide resistance in the small hive beetle. Rotation of classes of insecticides (with different modes of action) and metabolic synergists were suggested for the development of successful resistance management programs. To the best of our knowledge, this is the first study of the mechanisms of resistance in small hive beetle populations in Florida and suggests an urgent need for alternative control strategies for these serious pests of honeybee colonies.
\end{abstract}

Keywords: honeybee; small hive beetle; insecticide resistance; mechanisms of resistance; beekeeping

\section{Introduction}

A healthy and secure honeybee industry is valuable to modern agriculture, providing pollination services for more than 90 commercial crops which are estimated in the United States (U.S.) at USD 20 billion [1]. Nearly USD 9 billion worth of agricultural goods indirectly benefit from pollination by honeybees, such as almonds, alfalfa hay, meat and milk. In addition, honeybees make a significant contribution to biodiversity [2]. The health of managed and wild honeybee colonies has declined substantially over the past few years [3], and a drastic decline in honeybee populations poses a threat to agricultural sustainability and food security as well as to the ecosystem. A combination of causal factors, including parasites, pathogens, pesticides and beekeeping practices are cited as responsible for the increased colony mortality [4]. The parasitic mite Varroa destructor Anderson and Trueman (Varroa mite) is recognized as the major factor underlying colony loss in the U.S. and other countries. In addition to the Varroa mite's role as a vector of diseases associated with colony collapse disorder [5], infestation by Varroa contributes to stress and weakens honeybee colonies (immunodeficiency) [6]. The small hive beetle (Aethina tumida Murray), a new alien species native to sub-Saharan Africa, entered the United States through South 
Carolina [7] and was found in Florida in 1998 [8]. The small hive beetle has now spread to all continents but Antarctica [9,10]. It can cause substantial damage to apiculture and wild bees [11-13]. The economic losses to Florida beekeepers were estimated at USD 3 million in 1998 [14]. The small hive beetle has become a serious threat to apiculture [15] as well as the crops that rely on honeybees for pollination. The small hive beetles feed on honey, pollen and live brood, tunnel into and pierce wax combs and defecate in and cause stored honey to ferment, leading it to weep and froth away from the cells [16-22]. Neuman et al. [21] reported that even strong colonies of European honeybees infested with small hive beetle can perish within less than 2 weeks. In addition, the small hive beetle has the potential to act as vector of viral disease (deformed wing virus) and bacterial disease (American foulbrood) $[23,24]$.

Effective and sustainable control measures for the small hive beetle are yet to be developed. Several trapping devices for the small hive beetle were designed, but provided various degrees of success [25]. In the area of chemical control, the United State Department of Agriculture (USDA), Environmental Protection Agency (EPA) authorized an emergency use permit (Section 18 status) for coumaphos for in-hive treatments against the small hive beetle, but this failed to provide extended control of the pest [26,27]. Kanga and Somorin [28] indicated that fenitrothion, parathion, chlorpyrifos and methomyl were more toxic to the small hive beetle than coumaphos. Buchholz et al. [29] reported that formic acid and acetic acid were not successful in controlling field populations of the small hive beetle. A soil drench under infested colonies with permethrin (GardStar 40\% EC, Y-Tex Corporation, Cody, WY) was also used as a control measure against small hive beetle populations in the U.S., but its efficacy was dependent on the timing of the applications $[7,18,30]$. There are several problems associated with ground drenches as they do not prevent the spread of the small hive beetle and they require continuous treatments $[7,31,32]$.

The longtime exposure of small hive beetle populations to chemical pesticides used to control the Varroa mite as well as insecticides targeting the small hive beetle itself have resulted in the recent development of resistance to insecticides in field-collected small hive beetles [33]. The occurrence of resistance in the two major pests of honeybees (Varroa mite and small hive beetle) is of great concerns to beekeeping. Thus, there is an urgent need for strategies to manage that resistance.

The identification of the mechanisms of resistance to these insecticides is critical to optimize the likelihood of success in managing that resistance. Therefore, it is imperative to determine the genetic nature of resistance for the development of a resistance monitoring technique. Known mechanisms of resistance in beetles include enhanced metabolic degradation or decreased sensitivity of target sites [34,35]; decreased uptake resistance and behavioral resistance may supplement the effects of the major mechanisms. Thus, there is merit to expand this study to include other resistance-mediated factors in small hive beetle populations. Equally important is knowledge of the molecular nature of resistance, the number of genes associated with that resistance and the inheritance of each resistance mechanism. Such information will contribute to a better understanding of the evolution of resistance and has practical implications for resistance management in the field [36].

In this study, we provide the first evidence of the mechanisms of resistance to organophosphorus and pyrethroid insecticides in the small hive beetle. We determined the toxicity of insecticides alone or combined with metabolic and target site synergists. We also suggest a resistance management strategy for the small hive beetle in honeybee colonies. Our data provide useful insights for the development of a sustainable integrated pest management strategy which will extend the efficacy of all major classes of chemical pesticides used for control. 


\section{Materials and Methods}

\subsection{Small Hive Beetle}

Multiple field collections of more than a hundred adult small hive beetles from infested colonies were conducted from the apiary at FAMU Research and Cooperative Extension Center, Quincy, FL, Rish Tupelo apiary, Wewahitchka, FL, and Lee Bushong apiary in Monticello, FL. They were brought to the laboratory and adult beetles were removed using an aspirator and transferred into rearing jars (transparent wide mouth-harvest time jars, $800 \mathrm{~mL}$, which have a mesh screen lid insert). They were reared in the laboratory using the procedure described by Mürrle and Neumann [37] and Stuhl [38]. Water and humidity were provided in the jars by placing a dental-wicked water-filled plastic vial. The beetles were held at room temperatures of $27 \pm 1^{\circ} \mathrm{C}$ and $70 \pm 5 \%$ relative humidity and fed with honey-fortified artificial diet pollen substitutes (Global Patties, Butte, MT). The field-collected small hive beetles were exposed to diagnostic concentrations of insecticides in glass vials to separate susceptible individuals from resistant ones and establish the resistant colonies in the laboratory [33] for use in the bioassays. The adult small hive beetles used in the experimental runs were a week old and from the first two generations of laboratory-reared individuals.

\subsection{Synergism Bioassays}

Known synergists were used as diagnostic probes to determine the mechanisms of insecticide resistance in the small hive beetle. The synergism bioassays were conducted using the glass vial technique as described by Kanga and Somorin [28]. Five types of synergists were used; these included a mixed-function microsomal oxidase inhibitor (piperonyl butoxide (PBO)); a putative inhibitor of esterases (S,S,S,-tributyl phosphorotrithionate (DEF)); an inhibitor of carboxylesterase (triphenyl phosphate (TPP)); a glutathione-S-transferases inhibitor (diethyl maleate (DEM)); and a target site synergist (formamidine). The amount of synergists used in each experiment was $50 \mu \mathrm{g}$ per vial for $\mathrm{PBO}, 25 \mu \mathrm{g}$ per vial for DEF, $50 \mu \mathrm{g}$ per vial for DEM, $25 \mu \mathrm{g}$ per vial for TPP and $50 \mu \mathrm{g}$ per vial for formamidine. These concentrations of synergists were selected because in our pre-experimental runs with synergists only, they were the highest concentrations that were not lethal to the small hive beetle. Two sets of bioassays were developed in each experimental run. In one set, adult small hive beetles were treated with a mixture of insecticides and synergists, and in the second set adult small hive beetles were treated with the insecticide only. In each bioassay, $0.5 \mathrm{~mL}$ of insecticide only or a mixture of insecticide and synergist dissolved in ethanol were placed in $20 \mathrm{~mL}$ glass vials which were rolled until the ethanol dried and the insecticides or synergists coated the inner surfaces. Vials containing $0.5 \mathrm{~mL}$ of ethanol only were used as controls. We tested dilution ratios from $1.0 \times 10^{1}, 1.0 \times 10^{2}, 1.0 \times 10^{3}$, $1.0 \times 10^{4}, 1.0 \times 10^{5}, 1.0 \times 10^{6}$ and $1.0 \times 10^{7} \mu \mathrm{g}$ per vial for each insecticide. This provided concentrations of insecticides in each experiment ranging from 0.05 to $100 \mu \mathrm{g}$ per vial.

Eight concentrations of insecticide were tested per experimental run. Two unsexed adult small hive beetles were exposed to residues of insecticides coated in each vial and held at room temperature as described above; each vial served as a replicate for each concentration of insecticide tested. The bioassay was replicated on five separate dates with 10 replicates for each concentration [28]. Thus, we tested more than 270 beetles per insecticide with and without synergists. Mortality of the small hive beetle was determined $24 \mathrm{~h}$ post treatment. Adult small hive beetles that were unable to walk $10 \mathrm{~mm}$ when probed with a fine brush were recorded as dead.

\subsection{Statistical Analysis}

The bioassay data were analyzed using the POLO program of the Probit procedure [39]. The Abbott's formula [40] was used to adjust for mortality in the controls. The synergism ratios were determined by dividing the $\mathrm{LC}_{50}$ for the insecticide alone by that of the insecticide with synergists. The synergism ratios were not significant if the $95 \%$ confidence limits (CL) at the $\mathrm{LC}_{50}$ included 1.0 [41]. The slopes and intercepts of the two regression 
lines of the treatments were assessed to be the same using a likelihood ratio test of equality (equal slopes, equal intercepts). A ratio test of parallelism was used to assess whether the regression lines of the treatments were parallel (equal slopes) indicating that the slopes of the two lines were the same [41,42].

\section{Results}

\subsection{Resistance Associated with Mixed-Function Oxidases}

The toxicity of the pyrethroid fluvalinate to the small hive beetles increased by 10.67-fold when the insecticide was combined with the synergist PBO, compared to fluvalinate alone (Table 1). The $95 \%$ confidence limit (CL) of the synergism ratio at the $\mathrm{LC}_{50}$ did not include 1.0 [26]; therefore, the $\mathrm{LC}_{50}$ of fluvalinate alone and fluvalinate with the synergist were significantly different. In addition, the dose-response regression lines for fluvalinate alone and fluvalinate with PBO were found to be parallel $\left(\chi^{2}=0.84 ; \mathrm{df}=1\right.$; $p=0.360)$ but not equal $\left(\chi^{2}=169.02 ; \mathrm{df}=2 ; p=0.0001\right)[26,27]$. The findings suggest that mixed-function oxidases were major contributors of resistance to the pyrethroid fluvalinate in the small hive beetle populations.

Table 1. The toxicity of the pyrethroid fluvalinate and the organophosphate coumaphos with and without synergists to the small hive beetles.

\begin{tabular}{|c|c|c|c|c|c|}
\hline Insecticides & $\mathrm{N}^{1}$ & Slope \pm SE & $\mathrm{LC}_{50}(95 \% \mathrm{CL})^{2}$ & $\mathrm{SR}^{3}$ & $\chi^{2}(\mathrm{df})$ \\
\hline \multicolumn{6}{|l|}{ Pyrethroid } \\
\hline Fluvalinate & 400 & $3.39 \pm 0.34$ & $\begin{array}{c}22.29 \\
(19.02-26.02)\end{array}$ & - & $1.15(5)$ \\
\hline Fluvalinate with $\mathrm{PBO}$ & 320 & $2.97 \pm 0.58$ & $\begin{array}{c}2.09 \\
(1.47-2.77)\end{array}$ & $\begin{array}{c}10.67 \\
(7.86-14.88)\end{array}$ & $0.78(4)$ \\
\hline Fluvalinate with DEF & 320 & $2.07 \pm 0.29$ & $\begin{array}{c}9.62 \\
(7.58-14.74)\end{array}$ & $\begin{array}{c}2.32 \\
(1.51-3.27)\end{array}$ & $2.60(5)$ \\
\hline Fluvalinate with DEM & 320 & $2.09 \pm 0.32$ & $\begin{array}{c}27.04 \\
(19.53-38.44)\end{array}$ & $\begin{array}{c}0.82 \\
(0.59-1.20)\end{array}$ & $6.73(5)$ \\
\hline Fluvalinate with TPP & 280 & $2.73 \pm 0.56$ & $\begin{array}{c}14.98 \\
(9.56-22.64)\end{array}$ & $\begin{array}{c}1.48 \\
(0.91-2.25)\end{array}$ & $0.74(5)$ \\
\hline $\begin{array}{l}\text { Fluvalinate with } \\
\text { Formamidine }\end{array}$ & 280 & $3.11 \pm 0.48$ & $\begin{array}{c}21.01 \\
(15.98-27.47)\end{array}$ & $\begin{array}{c}1.06 \\
(0.78-1.40)\end{array}$ & $2.66(5)$ \\
\hline \multicolumn{6}{|l|}{ Organophosphate } \\
\hline Coumaphos & 320 & $3.27 \pm 0.70$ & $\begin{array}{c}120.26 \\
(100.02-148.62)\end{array}$ & - & $7.62(5)$ \\
\hline Coumaphos with $\mathrm{PBO}$ & 320 & $1.56 \pm 0.23$ & $\begin{array}{c}24.79 \\
(18.86-32.67)\end{array}$ & $\begin{array}{c}4.85 \\
(3.83-6.59)\end{array}$ & $9.92(5)$ \\
\hline Coumaphos with DEF & 320 & $2.93 \pm 0.46$ & $\begin{array}{c}48.07 \\
(39.64-58.35) \\
\end{array}$ & $\begin{array}{c}2.50 \\
(1.56-4.14) \\
\end{array}$ & $9.86(5)$ \\
\hline $\begin{array}{c}\text { Coumaphos with } \\
\text { DEM }\end{array}$ & 280 & $2.23 \pm 0.38$ & $\begin{array}{c}219.31 \\
(167.12-328.99)\end{array}$ & $\begin{array}{c}0.55 \\
(0.43-1.70)\end{array}$ & $5.81(5)$ \\
\hline Coumaphos with TPP & 280 & $2.20 \pm 0.40$ & $\begin{array}{c}245.74 \\
(184.82-385.78)\end{array}$ & $\begin{array}{c}0.49 \\
(0.39-1.63)\end{array}$ & $2.95(5)$ \\
\hline $\begin{array}{l}\text { Coumaphos with } \\
\text { Formamidine }\end{array}$ & 280 & $3.07 \pm 0.60$ & $\begin{array}{c}250.58 \\
(200.94-353.47)\end{array}$ & $\begin{array}{c}0.48 \\
(0.37-1.59)\end{array}$ & $1.44(5)$ \\
\hline
\end{tabular}

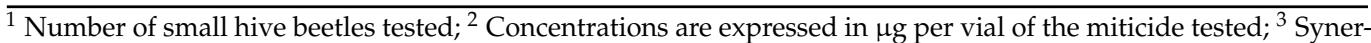
gism ratio (SR) calculated by dividing the $\mathrm{LC}_{50}$ for insecticide alone by the $\mathrm{LC}_{50}$ for insecticide with synergists.

For the organophosphate coumaphos, its toxicity to the small hive beetles increased by 4.85 -fold when the insecticide was combined with the synergist $\mathrm{PBO}$, compared to coumaphos alone (Table 1). The $95 \%$ confidence limit (CL) of the synergism ratio at the 
$\mathrm{LC}_{50}$ did not include 1.0 [41]; therefore, the effects of coumaphos alone and a mixture of coumaphos and synergist were significantly different. The dose-response regression lines for coumaphos alone and coumaphos with $\mathrm{PBO}$ were parallel $\left(\chi^{2}=0.79 ; \mathrm{df}=1\right.$; $p=0.491)$ but not equal $\left(\chi^{2}=111.04 ; \mathrm{df}=2 ; p=0.0001\right)$. The overall results suggest that mixed-function oxidases were major resistance factors to coumaphos in small hive beetle populations.

\subsection{Resistance Associated with Enhanced Metabolism by Esterase}

The toxic effects of fluvalinate on the small hive beetle increased by 2.32 -fold when the insecticide was combined with the synergist DEF as compared to fluvalinate alone (Table 1). The mixture of the insecticide with the synergist was significantly more toxic than the insecticide alone. The tests on the dose-response regression lines for fluvalinate alone and fluvalinate with DEF indicated that the lines were parallel $\left(\chi^{2}=0.59 ; \mathrm{df}=1 ; p=0.290\right)$ but $\operatorname{not}$ equal $\left(\chi^{2}=; \mathrm{df}=2 ; p=0.0001\right)$. Thus, the data suggest that the esterase-mediated factor was an additional mechanism of resistance to fluvalinate in small hive beetle populations.

The mixture of the organophosphate coumaphos and the synergist DEF was 2.5-fold more toxic to small hive beetles than coumaphos alone (Table 1). The synergism ratio was significant based on the failure of the $95 \%$ confidence limit (CL) at the $\mathrm{LC}_{50}$ values to bracket 1.0 [41]. The tests on the concentration-mortality regression lines for coumaphos alone and coumaphos with DEF indicated that the lines were parallel $\left(\chi^{2}=0.38 ; \mathrm{df}=1\right.$; $p=0.537)$ but not equal $\left(\chi^{2}=4016 ; \mathrm{df}=2 ; p=0.001\right)$. The results indicate small hive beetles have another mechanism of resistance to coumaphos through an esterase-mediated factor.

\subsection{Resistance Associated with Carboxylesterases}

Mortality data on fluvalinate with TPP did not indicate any significant synergism ratio ( $\mathrm{SR}=1.48$-fold) compared with fluvalinate alone (Table 1 ). In addition, testing the hypothesis about the dose-mortality regression lines indicated that regression lines of the two treatments were equal $\left(\chi^{2}=5.43 ; \mathrm{df}=2 ; p=0.066\right)$ and parallel $\left(\chi^{2}=0.96 ; \mathrm{df}=1\right.$; $p=0.327)$. The findings suggest that the enzyme carboxylesterase was not a mechanism of resistance to fluvalinate in small hive beetle populations.

The synergism ratio $(S R=0.49)$ of coumaphos alone and coumaphos with TPP was not significant (Table 1). Thus, the addition of the synergist TPP did not affect the toxicity of coumaphos to the small hive beetle. Further, the concentration-mortality regression lines of the two treatments were equal $\left(\chi^{2}=1.48 ; \mathrm{df}=2 ; p=0.477\right)$ and parallel $\left(\chi^{2}=0.47 ; \mathrm{df}=1\right.$; $p=0.393)$. These results suggest enhanced metabolism by the enzyme carboxylesterase was not involved in resistance to coumaphos in small hive beetle populations.

\subsection{Resistance Associated with Glutathione-S-Transferase}

The pyrethroid fluvalinate with the synergist DEM and fluvalinate alone had a synergist ratio of 0.82 ; thus, there were no significant differences in the toxicity to the small hive beetle between the two treatments (Table 1). In addition, the dose-mortality regression lines for fluvalinate alone and the mixture of fluvalinate with the synergist DEM were equal $\left(\chi^{2}=8.58 ; \mathrm{df}=2 ; p=0.075\right)$ and parallel $\left(\chi^{2}=0.74 ; \mathrm{df}=1 ; p=0.271\right)$. As a result, enhanced metabolism by glutathione-S-transferase was not involved in pyrethroid (fluvalinate) resistance in small hive beetles.

The synergist ratio of coumaphos alone and with the synergist DEM was 0.55-fold, thus the toxicity to the small hive beetle in the two treatments was similar (Table 1). In addition, hypothesis testing of the dose-mortality regression lines for both treatments indicated that the lines were equal $\left(\chi^{2}=6.30 ; \mathrm{df}=2 ; p=0.073\right)$ and parallel $\left(\chi^{2}=1.99 ; \mathrm{df}=1\right.$; $p=0.159$ ). As a result, enhanced metabolism by the enzyme glutathione-S-transferase was not a factor of resistance to coumaphos in small hive beetle populations. 


\subsection{Resistance Associated with Altered Target Site}

The toxicity of fluvalinate alone to the small hive beetle compared to the mixture of fluvalinate and the synergist formamidine was not significantly different $(S R=1.06)$, as the $95 \%$ confidence limit (CL) of the synergism ratio at the $\mathrm{LC}_{50}$ bracketed 1.0 [41]. In addition, the dose-mortality regression lines for both treatments indicated that the lines were equal $\left(\chi^{2}=0.30 ; \mathrm{df}=2 ; p=0.863\right)$ and parallel $\left(\chi^{2}=0.21 ; \mathrm{df}=1 ; p=0.644\right)$. These findings suggest that altered target site was not a mechanism of resistance to fluvalinate in small hive beetle populations.

The effects of coumaphos alone on small hive beetles compared to those of the mixture of coumaphos and the synergist formamidine were not significantly different ( $\mathrm{SR}=0.48$-fold). The tests on the concentration-mortality regression lines for coumaphos with and without formamidine indicated that the lines were equal $\left(\chi^{2}=5.55 ; \mathrm{df}=2\right.$; $p=0.062)$ and parallel $\left(\chi^{2}=5.21 ; \mathrm{df}=1 ; p=0.077\right)$. Therefore, altered target site was not a factor of resistance to coumaphos in small hive beetle populations.

\section{Discussion}

Our data suggest that the resistance mechanisms in small hive beetle populations were metabolic (mixed function oxidase and enhanced detoxification by esterases) to a pyrethroid (fluvalinate) and an organophosphate (coumaphos). Our assessments of the activities of carboxylesterase, glutathione-S-transferase and altered target site indicated that these enzymes were not involved in insecticide resistance in the small hive beetle in Florida. In terms of mechanisms of resistance in other species of beetle, Bloomquist et al. [34] reported target site resistance was the major mechanism of cyclodiene resistance in the red flour beetle, while Hojland et al. [35] and Willis et al. [43] suggested mixed function oxidases as the major factors of resistance to pyrethroids in the cabbage stem flea beetle. Our results are in agreement with the findings by Hojland et al. [35] and Willis et al. [43].

Because the mechanisms of insecticide resistance to fluvalinate and coumaphos in the small hive beetle were mainly metabolic, the use of metabolic synergists (such as PBO and DEF) to manage that resistance have a high likelihood of success. These synergists may be added to the insecticides during formulations to inhibit the enzyme for resistance and therefore prolong the effectiveness of the insecticides. The small hive beetles were selectively resistant to the classes of insecticides tested and within each class of insecticides [28,42]. Therefore, a resistance management strategy based on the rotation of insecticide classes with different modes of action may be successful. The need to conserve susceptibility of the small hive beetle to existing insecticides is critical because there are limited alternative insecticides for use in the beekeeping industry.

Overall, our understanding of these resistance factors in the small hive beetle will provide useful information needed to develop successful resistance management programs which may combine the rotation of classes of insecticides (with different modes of action) with selected synergists such as $\mathrm{PBO}$ and DEF. However, additional studies on the genetic nature and the inheritance of that resistance should provide a better understanding of the evolution of resistance in the small hive beetle for the development of a sustainable and integrated resistance management program.

\section{Conclusions}

Despite the economic importance of honeybees through honey production and crop pollination services, their populations have continued to decline over the years due to several factors. The most important is the destructive impact of the Varroa mite and small hive beetle. In addition to insecticide resistance in the Varroa mite, the recent onset of resistance to fluvalinate and coumaphos in the small hive beetle is of great concern for beekeepers. In this study, we determined the mechanisms of insecticide resistance in small hive beetle populations: these findings are key factors in developing successful resistance management programs. The detoxification enzymes esterase and mixed function oxidases were significantly suppressed by the metabolic synergists DEF and PBO, which indicated 
that enhanced metabolism by esterase and mixed function oxidase are the main factors of resistance to organophosphates and pyrethroids in the small hive beetle populations.

The overall data suggest that rotation of classes of insecticides (with different modes of action) and the use of synergists would be important components for sustainable and integrated resistance management strategies.

Author Contributions: L.H.B.K. and W.M. developed and conducted the experiments, analyzed the data and drafted the paper. A.A. was responsible for advising and supervising the experimental runs. L.H.B.K. was involved in writing, reviewing and editing the manuscript. L.H.B.K. was responsible for obtaining funding. All authors have read and agreed to the published version of the manuscript.

Funding: This study was supported by USDA-NIFA, grant number 2014-38821-22401.

Institutional Review Board Statement: Not applicable.

Informed Consent Statement: Not applicable.

Acknowledgments: We are grateful to Janice Peters (Florida A\&M University) for providing technical support and useful discussions and reviews of the manuscript. We are also grateful to Worrel Diedrick (FAMU) for his technical assistance and for maintaining healthy honeybee colonies for use in this study.

Conflicts of Interest: The authors declare no conflict of interest.

\section{References}

1. Frankie, G.; Thorp, R.; Coville, R.; Etter, B. California Bees and Blooms: A Guide for Gardeners and Naturalists, 1st ed.; Heyday Press: Berkeley, CA, USA, 2014.

2. Buchmann, S.L.; Nabhan, P.G. The Forgotten Pollinators; Shearwater Books; Island Press: Washington, DC, USA, 1996.

3. NAS (National Academy of Sciences). Status of Pollinators in North America; National Academy Press: Washington, DC, USA, 2012.

4. Cox-Foster, D.L.; Conlan, S.; Holmes, E.C.; Palacios, G.; Evans, J.D. A metagenomic survey of microbes in honeybee colony collapse disorder. Science 2007, 318, 283-287. [CrossRef] [PubMed]

5. Di Prisco, G.; Pennacchio, F.; Caprio, E.; Boncristiani, F.H., Jr.; Evans, J.D.; Chen, Y. Varroa destructor is an effective vector of Israeli acute paralysis virus in the honeybee, Apis mellifera. J. Gen. Virol. 2011, 92, 151-155. [CrossRef] [PubMed]

6. Yang, X.; Cox-Foster, D.L. Impact of an ectoparasite on the immunity and pathology of an invertebrate: Evidence for host immunosuppression and viral amplification. Proc. Natl. Acad. Sci. USA 2005, 102, 7470-7475. [CrossRef] [PubMed]

7. Hood, W.M. Overview of the small hive beetle, Aethina tumida, in North America. Bee World 2000, 81, 129-137. [CrossRef]

8. Elzen, P.J.; Baxter, J.R.; Westervelt, D.; Randall, C.; Delaplane, K.S.; Cutts, L.; Wilson, W.T. Field control and biology studies of a new pest species, Aethina tumida Murray (Coleoptera: Nitidulidae), attacking European honeybees in the Western Hemisphere. Apidologie 1999, 30, 361-366. [CrossRef]

9. Neumann, P.; Pettis, J.S.; Schäfer, M.O. Quo vadis Aethina tumida? Biology and control of small hive beetles. Apidologie 2016, 47, 427-466. [CrossRef]

10. Lee, S.; Hong, K.J.; Cho, Y.S.; Choi, Y.S.; Yoo, M.S.; Lee, S. Review of the subgenus Aethina Erichson s. str. (Coleoptera: Nitidulidae: Nitidulinae) in Korea, reporting recent invasion of small hive beetle, Aethina tumida. J. Asia-Pac. Entomol. 2017, 20, 553-558. [CrossRef]

11. Hoffmann, D.; Pettis, J.S.; Neumann, P. Potential host shift of the small hive beetle (Aethina tumida) to bumblebee colonies (Bombus impatiens). Insect Soc. 2008, 55, 153-162. [CrossRef]

12. Wade, R. Keeping out Small Hive Beetles. Aussie Bee. Online Article 18. 2012. Available online: http://www.aussiebee.com.au/ aussiebeeonline018.pdf (accessed on 5 April 2021).

13. Peña, W.L.; Carballo, L.F.; Lorenzo, J.D. Reporte de Aethina tumida Murray (Coleoptera, Nitidulidae) en colonias de la abeja sin aguijón Melipona beecheii Bennett de Matanzas y Mayabeque. Rev. Salud Anim. 2014, 36, 201-204.

14. Ellis, J.D.; Neumann, P., Jr.; Hepburn, R.; Elzen, P.J. Longevity and reproductive success of Aethina tumida (Coleoptera: Nitidulidae) fed different natural diets. J. Econ. Entomol. 2002, 95, 902-907. [CrossRef]

15. Ellis, J.D.; Hepburn, H.R. An ecological digest of the small hive beetle (Aethina tumida), a symbiont in honeybee colonies (Apis mellifera). Insect. Soc. 2006, 53, 8-19. [CrossRef]

16. Lundie, A.E. The Small Hive Beetle: Aethina tumida. Science Bulletin 220; Entomological Series 3; Union of South Africa Department of Agriculture and Forestry: Pretoria, South Africa, 1940; p. 30.

17. Sanford, M.T. Small Hive Beetle (Aethina tumida). Apicultural Information and Issues, University of Florida, Cooperative Extension Newsletter Topics. APIS. 1999. Available online: http:/ / apis.ifas.ufl.edu/threads/smbeetle.htm (accessed on 6 March 2021).

18. Neumann, P.; Elzen, P.J. The biology of the small hive beetle (Aethina tumida,) (Coleoptera: Nitidulidae): Gaps in our knowledge of an invasive species. Apidologie 2004, 35, 229-247. [CrossRef] 
19. Spiewok, S.; Pettis, J.S.; Duncan, M.; Spooner-Hart, R.; Westervelt, D.; Neumann, P. Small hive beetle, Aethina tumida, populations I: Infestation levels of honeybee colonies, apiaries and regions. Apidologie 2007, 38, 595-605. [CrossRef]

20. Ellis, J.D.; Delaplane, K.S. Small hive beetle (Aethina tumida) oviposition behavior in sealed brood cells with notes on the removal of the cell contents by European honeybees (Apis mellifera). J. Apic. Res. 2008, 47, 210-215. [CrossRef]

21. Neumann, P.; Hoffmann, D.; Duncan, M.; Spooner-Hart, R. High and rapid infestation of isolated commercial honeybee colonies with small hive beetles in Australia. J. Apic. Res. Bee World 2010, 49, 343-344. [CrossRef]

22. Hood, W.M. Handbook of Small Hive Beetle IPM. Clemson University, Cooperative Extension Service. Extension Bulletin. 2011. Available online: http://www.extension.org/sites/default/files/Handbook_of_Small_Hive_Beetle_IPM.pdf (accessed on 4 April 2021).

23. Eyer, M.; Chen, Y.P.; Schafer, M.O.; Pettis, J.S.; Neumann, P. Small hive beetle, Aethina tumida, as a potential biological vector of honeybee viruses. Apidologie 2009, 40, 419-428. [CrossRef]

24. de Graaf, D.C.; Alippi, A.M.; Antúnez, K.; Aronstein, K.A.; Budge, G.; De Koker, D.; De Smet, L.; Dingman, D.W.; Evans, J.D.; Foster, L.J.; et al. Standard methods for American foulbrood research. J. Apic. Res. 2013, 52, 1-28. [CrossRef]

25. Hood, W.M. The small hive beetle, Aethina tumida: A review. Bee World 2004, 85, 51-59. [CrossRef]

26. Ellis, J.D.; Delaplane, K.S. The effects of three acaricides on the developmental biology of small hive beetles (Aethina tumida). J. Apic. Res. Bee World 2007, 46, 256-259. [CrossRef]

27. Neumann, P.; Hoffmann, D. Small hive beetle diagnosis and control in naturally infested honeybee colonies using bottom board traps and CheckMite+ strips. J. Pest. Sci. 2008, 81, 43-48. [CrossRef]

28. Kanga, L.H.B.; Somorin, A.B. Susceptibility of the small hive beetle, Aethina tumida (Lepidoptera: Nitidulidae), to insecticides and insect growth regulators. Apidologie 2012, 43, 95-102. [CrossRef]

29. Buchholz, S.; Merkel, K.; Spiewok, S.; Imdorf, A.; Pettis, J.S.; Westervelt, D.; Ritter, W.; Duncan, M.; Rosenkranz, P.; Spooner-Hart, R.; et al. Organic acids and thymol: Unsuitable for alternative control of Aethina tumida (Coleoptera: Nitidulidae)? Apidologie 2011, 42, 349-363. [CrossRef]

30. Schmolke, M.D. A Study of Aethina tumida: The Small Hive Beetle; Certificate in Field Ecology Project Report; University of Rhodesia: Harare, Zimbabwe, 1974; p. 178.

31. Torto, B.; Fombong, A.T.; Arbogast, R.T.; Teal, P.E. Monitoring Aethina tumida (Coleoptera: Nitidulidae) with baited bottom board traps: Occurrence and seasonal abundance in honeybee colonies in Kenya. Environ. Entomol. 2010, 39, 1731-1736. [CrossRef]

32. Mutinelli, F.; Montarsi, F.; Federico, G.; Granato, A.; Ponti, A.M.; Grandinetti, G.; Chauzat, M.P. Detection of Aethina tumida Murray (Coleoptera: Nitidulidae) in Italy: Outbreaks and early reaction measures. J. Apic. Res. 2014, 53, 569-575. [CrossRef]

33. Kanga, L.H.B.; Marechal, W.; Legaspi, J.C.; Haseeb, M. First report of insecticide resistance to organophosphates and pyrethroids in the small hive beetle (Coleoptera: Nitidulidae) and development of a resistance monitoring technique. J. Econ. Entomol. 2021, 114, 922-927. [CrossRef]

34. Bloomquist, J.R.; Beeman, R.W.; Clark, J.M. Mechanisms underlying cyclodiene resistance in the red flour beetle, Tribolium castaneum (Herbst). Pestic. Biochem. Physiol. 1993, 45, 154-165.

35. Hojland, D.H.; Nauen, R.; Foster, S.P.; Williamson, M.S.; Kristensen, M. Incidence, spread and mechanisms of pyrethroid resistance in European populations of the cabbage stem flea beetle, Psylliodes chrysocephala L. (Coleoptera: Chrysomelidae). PLoS ONE 2015, 10, e0146045. [CrossRef]

36. Ffrench-Constant, R.H. The molecular genetics of insecticide resistance. Genetics 2013, 194, 807-815. [CrossRef]

37. Mürrle, T.; Neumann, P. Mass production of small hive beetles (Aethina tumida, Coleoptera: Nitidulidae). J. Apic. Res. 2004, $43,144-145$.

38. Stuhl, C.J. Survival and reproduction of small hive beetle (Coleoptera: Nitidulidae) on commercial pollen substitutes. Fla. Entomol. 2017, 100, 693-697.

39. Russell, R.M.; Robertson, J.L.; Savin, N.E. POLO: A new computer program for Probit analysis. Bull. Entomol. Soc. Am. 1977, 23, 209-213. [CrossRef]

40. Abbott, W.S. A method of computing the effectiveness of an insecticide. J. Econ. Entomol. 1925, 18, 265-267. [CrossRef]

41. Robertson, J.; Preisler, H. Pesticide Bioassays with Arthropods, 1st ed.; CRC Press: Boca Raton, FL, USA, 1992.

42. Kanga, L.H.B.; Marshall, K.; Legaspi, J.C. Mechanisms of insecticide resistance in field populations of the varroa mite (Acari: Mesostigmata: Varroidae) in Florida. Fla. Entomol. 2016, 99, 325-326. [CrossRef]

43. Willis, C.E.; Foster, S.P.; Zimmer, C.T.; Elias, J.; Chang, X.; Field, L.M.; Williamson, M.S.; Davies, T.E. Investigating the status of pyrethroid resistance in UK populations of the cabbage stem flea beetle (Psylliodes chrysocephala). Crop Prot. 2020, 138, 105316. [CrossRef] 